\title{
"JUSTICE" AND OTHER NON-ECONOMIC GOALS OF ANTITRUST
}

\author{
Louis B. Schwartz †
}

\section{(Comments on Pitofsky, The Political Content of Antitrust)}

Commissioner Pitofsky's admirable delineation and defense of the role of political considerations in antitrust law exhibits a moderation not required of an academic like me. I would invoke a broader range of congressional history to demonstrate the will of Congress that putative economic gains should not be the exclusive or decisive factor in resolving antitrust controversies. I would not yield as freely as he does to the dogma that the antitrust laws protect "competition not competitors," because the goals of justice and the antitrust laws sometimes demand protection of competitors. I find, as he does not, clear evidence of congressional purpose to "create procedural protection for distributors." Far from dismissing such concerns as "playing no useful role" in antitrust interpretation, I see them serving the very useful role of preventing abuse of power when the growth of power cannot be checked. Further, I see the role of non-economic considerations not merely as a "tie-breaker," but as calling for a definite shift in burden of proof or persuasion, so that practices and structures with anti-competitive potential can be justified only on clear and convincing evidence of economic gain to be passed on to the public. Finally, I miss in the Pitofsky analysis any reference to that venerable non-economic goal of government, namely justice. Never, despite repeated demonstrations by economic modelists that price discrimination may optimize allocation of resources, has Congress wavered from its adherence to the view that it is "unjust discrimination" to charge different customers different prices for identical services. ${ }^{1}$

Regarding the range of congressional manifestations of Congress' willingness to pursue its deconcentration goals if need be at some economic cost, Professor Pitofsky points out that the noneconomic goals are clear in the legislative history of antitrust enactments supplementing the Sherman Act, and that "arguably ... these subsequent expressions define Congress' vague intentions in

+ Benjamin Franklin Professor of Law, University of Pennsylvania. B.S. 1932, J.D. 1935, University of Pennsylvania.

1 See Interstate Commerce Act, 49 U.S.C. $\$ 2$ (1970). 
earlier enactments." In this connection, his footnote 31 reminds us that the antitrust laws constitute an "interrelated network," "interlacing statutes."

There are more elements in this network than he mentions or than is generally appreciated. The Reclamation Act of 1902 limited the sale of water from federal irrigation projects so that no single owner might benefit for more than 160 acres. $^{2}$ In section 11 of the Public Utility Holding Company Act of 1935, ${ }^{3}$ Congress declared its tolerance for giant utility combines if they effected "substantial economies," 4 but only if they were "not so large . . . as to impair the advantages of localized management." 5 The Small Business Act of $1942^{\circ}$ declared congressional policy to assure "smallbusiness concerns [a] fair proportion" of government procurement contracts under arrangements that even permitted the payment of higher prices to small-business suppliers. ${ }^{7}$ The Surplus Property Act of $1944^{8}$ directed the federal government to dispose of war production facilities under standards that included preference for smaller purchasers and "strengthen[ing] and preserv[ing] the com. petitive position of small business concerns." 9 Our banking regulation clearly subordinates "efficiency" considerations to considerations of excessive concentration of power when it seeks to prevent banks and bank holding companies from extending their operations into "non-banking" business." A judge or administrator who wishes to be responsive to the will of Congress can hardly fail to catch the drift of these legislative enactments. Collectively they portray a view of the public interest that must pervade the interpretation of the antitrust laws, whether or not one approves of all these "preferences" for small business.

The non-economic component of American antitrust policy stands out even more strikingly if one broadens the perspective

243 U.S.C. $\$ 431$ (1976). See Ivanhoe Irrigation Dist. v. McCracken, 357 U.S. $275,294-97$ (1958).

315 U.S.C. $\$ 79 \mathrm{k}(1976)$.

4 Id. $\$ 79 \mathrm{k}(\mathrm{b})(\mathrm{I})(\mathrm{A})$.

5 Id. $\$ 79 \mathrm{k}(\mathrm{b})(\mathrm{I})(\mathrm{C})$. Cf. SEC v. New England Elec. Sys., 384 U.S. 176 (1966).

615 U.S.C. $\$ \$ 631-647$ (1976).

715 U.S.C. $\$ 631$ (a) (1976).

8 Pub. L. No. 457,58 Stat. 765 (1944) (current version at 40 U.S.C. $\$ 484$ and 50 U.S.C. $\$ 1622$ (d) (1970)).

9 Id. $\$ 2(\mathrm{~d})$. Similar provisions were incorporated into $\$ 207$ of the Federal Property and Administrative Services Act of 1949, 40 U.S.C. $\S 488$ (1976).

10 See, e.g., Bankamerica Corp. v. Board of Governors of the Fed. Reserve Sys., 491 F.2d 985 (9th Cir. 1974); Arnold Tours, Inc. v. Camp, 472 F.2d 427 (Ist Cir. 1972). 
beyond congressional legislation to consider that major historic event, American imposition of antitrust measures upon conquered Germany and Japan after World War II. No one then suggested that our zeal for industrial deconcentration there was an attempt to impose diseconomies on the defeated. Some believed that the rapid reconstruction of those devastated economies called for decartelization and decentralization. But clearly the dominant motivation was political: a desire to create alternative centers of power that could not readily be marshalled behind authoritarian regimes. I have elsewhere explored "Authoritarian Aspects of Bigness" as a political theme in the antitrust symphony. ${ }^{11}$ Finally, it is well known that one goal of the antitrust laws is to avert the need for massive and ongoing government regulation or nationalizationprecisely the political goal that has brought even sophisticated businessmen to join in the American consensus supporting the antitrust principle, however avidly each businessman may seek exemption for his own business.

The dogma that "antitrust laws protect competition not competitors" overstates the case and ignores considerations of justice. One must amend that declaration by adding at least the following qualification: "unless individual competitors must be protected in the interests of preserving competition." A conspiracy to put a single small competitor out of business violates the Sherman Act even if there is no showing of significant impact on competition generally. ${ }^{12}$ In the Robinson-Patman Act, ${ }^{13}$ Congress explicitly extended the anti-discrimination ban to attempts to eliminate "a competitor" as well as to cases of impairment of competition. ${ }^{14}$ These may be regarded as instances of Congress" concern with "incipient" impairment of competition or desire to prevent transactions, trivial in themselves, which might "trigger" a series of similar transactions. But they also may be seen as a congressional concern for a non-economic goal: "justice," in the sense of fair and equal treatment of persons in like situations.

That the purpose of the antitrust laws includes "procedural protection for distributors" seems clear from the Automobile Dealer

11 Schwartz, Institutional Size and Individual Liberty: Authoritarian Aspects of Bigness, 55 Nw. U.L. Rev. 4 (1960); Schwartz, American Antitrust Laws and Free Enterprise in 2 Swiss ReWIEW OF INTERNatIoNAL ANTITRUST LAW 3 (January 1978).

12 See, e.g., Klors, Inc. v. Broadway-Hale Stores, Inc., 359 U.S. 207 (1959). But see Oreck Corp. v. Whirlpool Corp., 579 F.2d 126 (2d Cir.), cert. denied, 99 S. Ct. 340 (1978) (three Justices dissenting).

1315 U.S.C. $\$ \$ 13-13 \mathrm{~g}, 21 \mathrm{a}$ (1976).

14 See FTC v. Morton Salt Co., 334 U.S. 37 (1948). 
Franchise Act of $1956,{ }^{15}$ which undertakes to require auto manufacturers to "act in a fair and equitable manner" in terminating or failing to renew dealer franchises. ${ }^{18}$ This legislation was entitled "An Act to supplement the antitrust laws of the United States, in order to balance the power now heavily weighted in favor of automobile manufacturers." 17 Some, including myself, may see the Auto Dealer Franchise Act as misguided or as setting a dangerous precedent for unwarranted "status" protection of dealers generally, but it can hardly be denied that Congress here purported to exercise, as part of its antitrust concerns, a supervision over fair procedure and justice in economic relationships. Moreover, cases such as Radiant Burners, Inc. v. Peoples Gas Light Co., ${ }^{18}$ and Silver $v$. New York Stock Exchange, ${ }^{10}$ show that the Sherman Act itself can be invoked to guarantee procedural fairness when an industry is engaged in self-regulation. Radiant Burners was given an opportunity to prove that its ceramic burner qualified for the "seal of approval" by the trade association. Silver was guaranteed notice and opportunity for hearing before his private wire connections with an exchange member could be cut off. It is hardly surprising that the antitrust laws, which the Supreme Court has compared to the "Magna Carta" and the "Bill of Rights," 20 should incorporate a strain of fourteenth amendment due process, procedural as well as substantive. ${ }^{21}$ Similarly, it is easy to detect the fourteenth amendment theme of "equal protection of the laws" (the private commercial laws enacted by dominant firms and oligopolists) in the legislation against price and service discrimination. ${ }^{22}$ Others have noted as relevant to the debate over concentration that there is evidence that monopolistic enterprises discriminate against blacks more frequently than competitive enterprises. ${ }^{23}$

1515 U.S.C. $\$ \S 1221-1225$ (1976).

16 Id. $\$ \$ 1221(\mathrm{e}), 1222$.

17 Automobile Dealer Franchise Act, ch. 1078, 70 Stat. 1125 (1956) (current version at 15 U.S.C. $\$ \$ 1221-1225$ (1976)).

18364 U.S. 656 (1961).

10373 U.S. 341 (1963).

20 United States v. Topco Associates, 405 U.S. 596, 610 (1972).

21 Cf. A. Berue, Power 373-81 (1967) ("Corporate Regulations as 'Laws' under the Fourteenth Amendment").

22 Cf. FTC v. Sun Oil Co., 371 U.S. 505, 520 (1963) (citing the House Committee's view that the "guiding idea" of the Robinson-Patman Act was "the preservation of equality of opportunity as far as possible to all who are usefully employed in the service of distribution and production . . H.R. RER. No. 2287, 74th Cong., 2d Sess. 6.").

23 See Shepard, Market Power and Racial Discrimination in White Collar Employment, 14 ANTITrust BuLx. 141 (1969). 
The difficult question is not whether non-economic considerations are a proper, indeed conventional, component of the antitrust calculus, but how to take them into account. Pitofsky answered at the conference that political concerns may serve as "tie-breaker in individual cases," and as "limited factors that influence the way in which prospective rules are designed to accomplish antitrust objectives." I would go further:

(1) Except in criminal prosecutions, the weight of the noneconomic and non-quantitative goals of antitrust should shift to anyone seeking to justify a monopoly or a "suspect" anti-competitive practice the burden of persuading the tribunal that the justification is established by clear and convincing evidence. ${ }^{24}$ Such a rule would operate not merely in cases in which the judge may be left undecided by the economic evidence ( $a$ "tie"), but also when he believes that the balance of evidence slightly favors the justification.

(2) A proper deference to the non-economic goals of antitrust and to the uncertainties of many economic measurements would affect the way certain economic testimony is handled. For example, where there is an issue as to defendant's market share and, as usual, conflicting market boundaries are supported by evidence, the tribunal might be guided by the rule that the narrowest reasonable geographic and product boundaries would be accepted. ${ }^{25}$ Similarly, when "effect on competition" is the criterion of legality, an adverse effect in one market should suffice to condemn the transaction without exploring the possible pro-competitive impact in another market. ${ }^{28}$ So also a court giving proper deference to the political elements of the anti-merger laws would "tilt" towards rather than away from a reasonable administrative judgment that the acquiring company was a potential entrant. ${ }^{27}$ Note that these pro-

24 See United States v. Grinnell Corp., 236 F. Supp. 244 (D.R.I. 1964) (Wyzanski, J.), aff'd with modification of decree, 384 U.S. 563 (1966).

25 See, e.g., United States v. E.I. duPont de Nemours \& Co., 353 U.S. 586 (1957); United States v. International Boxing Club, 348 U.S. 236 (1955); Reynolds Metal Co. v. FTC, 309 F.2d 223 (D.C. Cir. 1962).

26 See United States v. Topco Associates, Inc., 405 U.S. 596 (1972); United States v. Philadelphia National Bank, 374 U.S. 321 (1963).

Among recent examples of the undermining of prophylactic rules, reflecting inadequate deference to non-economic goals of antitrust, are Continental T.V., Inc. v. GTE Sylvania Inc., 433 U.S. 36 (1977) (repeal of per se prohibition of vertical territorial restraints; balancing of putative interbrand competitive gains against obvious loss of intrabrand competition); United States v. Marine Bancorporation, 418 U.S. 602 (1974) (retreating from the rule that mergers would be judged almost entirely on the basis of market shares and concentration); United States v. General Dynamics Corp., 415 U.S. 486 (1974).

27 But see British Oxygen Corp. v. FTC, 529 F.2d 196 (2d Cir. 1976). 
posals are not confined to "prospective" rule-making, as Pitofsky suggests, but apply in cases in which existing rules of law are interpreted in application to past transactions.

(3) A proper deference to the non-economic goals of antitrust and to the unreliability of official discrimination between "good" and "bad" performance by enterprises would lead to a greater receptivity to per se and other prophylactic antitrust rules. Such rules concededly bar some transactions for which plausible economic justifications can be made out. They embody a judgment that the economic gain infrequently sacrificed in such transactions is more than counterbalanced by more effective administration in the majority of cases in which both economic and non-economic goals will be served by strict enforcement.

(4) Recognition of the non-economic goals of antitrust warrants a pro-antitrust resolution of controversies over the bane or benefit of vertical and conglomerate mergers, the desirability of a "shared monopoly" approach to oligopoly, and the desirability of breaking up persistent monopolies even if no "predatory" actions can be proved. 